\title{
Carta do editor
}

O Instituto dos Advogados Brasileiros realizou, recentemente, em sua sede, sob a coordenação do professor Rogério Lauria Tucci, um Ciclo de Conferências sobre a Reforma Penal. Dele participaram o professor Francisco de Assis Toledo, coordenador das Comissões encarregadas da revisão dos projetos da Parte Geral do Código Penal, do Código de Processo Penal e da Lei de Execução Penal, bem como os professores Jair Leonardo Lopes, René Ariel Dotti, José Frederico Marques, Weber Martins Batista, Paulo La- deira de Carvalho e Plínio de Oliveira Corrêa, além do próprio coordenador do Ciclo, professor Rogério Lauria Tucci.

Tendo sido remetidos os projetos de Reforma Penal ao Congresso Nacional decidiu a Revista do Serviço Público editar as conferências cedidas pelo Instituto dos Advogados Brasileiros, por julgar que sua divulgação concorrerá para expandir o debate sobre reforma de interesse nacional. 